\title{
Some Psychological Aspects of War
}

\section{Clyde B. Moore}

To cite this article: Clyde B. Moore (1916) Some Psychological Aspects of War, The Pedagogical Seminary, 23:3, 367-386, DOI: 10.1080/08919402.1916.10534455

To link to this article: http://dx.doi.org/10.1080/08919402.1916.10534455

曲 Published online: 30 Aug 2012.

Submit your article to this journal $\widetilde{ }$

III Article views: 6

Q View related articles $\longleftarrow$ 


\title{
SOME PSYCHOLOGICAL ASPECTS OF WAR
}

\author{
By Clyde B. Moode, Clark University
}

One of the primary interests of living beings has been the business of killing. No matter where in the scale of life we select a type-be it a low or higher form-this element seems to be present in animal life. Cannon (18) points out that " it is in the highest degree natural that feelings of hostility often burn with fierce intensity, and then, with astonishing suddenness, that all the powers of the body are called into action-for the strength of the feelings and the quickness of response measure the chances of survival in a struggle where the issue may be life or death."

The history of the race teems with examples of "these feelings of hostility" that are "called into action." Man is essentially a killer. Apparently he has exercised this function in every possible direction. $\mathrm{He}$ is a fighter-pugnacious and such a social psychologist as McDougall (39) asserts that there is no reason to believe that the instinct for fighting and killing has grown weaker through centuries of civilization but that rather the opposite is true. In the long process of racial growth-and in the overcoming of other animalsman has been the successful killer. He has proven his superiority not so much because of his.so-called reason but because of his destructive power. Apparently he delights in killing the higher forms rather than the lower. The theory is advanced that the primary reason for our having the quest for the "missing link" is because man has killed him. $\mathrm{He}$ finds the killing instinct surging up more strongly as his foe or victim is advanced along the scale of life. The extermination of primitive peoples by the so-called civilized was very slow at first but after a reaction set in and the primitive people learned the art of killing-if such it be-then the process is rapid and the plans become more elaborate. The extermination of certain tribes of the American Indians serves as an example. The professional Indian scout or fighter was a sort of a specialist or post-graduate in the art of Indian killing and only disappeared as such when the Indian was beaten into submission and by his submissive attitude took away the pleasure of the fight.

McDougall asserts that it is stronger in European peoples 
than it ever was in primitive man and this is not a comment contemporaneous with the European war but appeared in 1908 as a part of the results in his study of society from the psychological viewpoint.

Apparently man in his evolutionary trend is being held more tenaciously by this instinct of fighting and killing. Chamberlain (10) says in his "Foundations of the Nineteenth Century," "The most ingenious dynamo machine does not raise men one inch over the earth surface which is common to all creatures; all such things denote merely a new accumulation of strength in the struggle for existence; man becomes thereby in a way a more highly potential animal." The developments in Europe during the great European war seem to substantiate these claims of both Chamberlain and McDougall and specific illustrations with which the literature is freighted only add emphasis to the plain fact that man is a killer.

If the killing, fighting instinct has in any way been sugarcoated by English magnanimity or German "Kultur" the reports from the trenches fail to corroborate it. Nor can we only point a finger of scorn at Europe. In our fair America who-in the calm of sane thought-can point with pride to the wholesale devastation and its accessory effects in Sherman's March to the Sea or to the abominable conditions existing in Andersonville and Libby prisons during our Civil War? And here it was a war not only within a race but within a nation and in some cases within the bonds of family ties.

During the past fifty years there has been marvelous progress in many lines. Much has been said and written concerning it. The moralists have attempted to show that the days of war and contention are all but a thing of the past. They acclaim with a liberal interpretation the words of the prophet, "And they shall beat their swords into plowshares, and their spears into pruning hooks; nation shall not lift up sword against nation, neither shall they learn war any more." This oriental poetry and the ecstatic moods of those who repeat it may point to a "consummation devoutly to be wished" but which is subject to the inertia of the philum.

Relatively the instinct to fight has not undergone such a vast change. The great change has come most recently in the fighting machinery. Machine guns, aeroplanes, submarines, bombs, howitzers, deadly gas generators. giant siege guns, wireless telephones and telegraph have been fashioned into a mighty vehicle of war that serves to express this instinct as never before. The fighting attitude prevails. It always hac nrevailed and the end is not yet.

The attitude to fight and to kill is deeply ingrained. Pow- 
erful instincts and emotions seize upon individuals in groups and "spread like wildfire into larger and larger aggregations of men, until vast populations are shouting and clamoring for war." Says Cannon- "To whatever extent military plans are successful in devising a vast machine for attack or defense, the energies that make the machine go are found in the last analysis, in human beings who, when the time for action comes, are animated by these surging elemental tendencies which assume control of their conduct and send them madly into conflict."

In all this recital of fighting and killing and wanting to kill and the suggestion that the trend is becoming more pronounced the question as to why it is or why it should be is forced upon us. We have been taught from parent, teacher, press and pulpit that all this is wrong. From the decalogue to the details of a city ordinance or perhaps to the precepts of teacher and parent, "thou shalt not kill" or "thou shalt not fight," has been the guide. What is it that tramples under foot these tenets that we have long held sacred? Why does McDougall or any other suggest that as our civilization advances we become more prone to kill? Why does he refer to Europe, the center of our best in civilization, as the place where the tendency is most pronounced?

It is not in the approval of national laws. Even international laws and treaties seem to be formed to prevent it. The school, the church, the press, all apparently teach that killing is the one thing to be abhorred and all in all the consensus of public opinion seems normally against fighting, against killing, against war. If all this be true where may a cause be found. Titchener says (59), "We come, again and again, upon evidence that our own determining tendencies are inherited." Man is termed a rational being, but no amount of training and culture can obliterate instinctive tendencies. Perhaps the highest and best training should not attempt any such thing. At any rate the instincts are present and active. The fighting instinct is easily aroused. But where may we find the thing that so deeply stirs the soul? Is there an instinct or group of instincts that in the final analysis produce war? There are such instincts, though they may not be commonly recognized.

President G. Stanley Hall (23) postulates the two poles of experience as being brought to a focus in the sense that all fears and phobias, on the one hand, are ultimately the fear of death. or thanatophobia, while at the other we have the culmination of all desires and wishes in the gratification of love. "The one is the great negation. and the other the supreme affirmation of the will to live." These two poles of 
experience mark the boundaries of the known span of life. In the final analysis the motives of the folk soul are here to be found. Man instinctively fears death. It is his philogenetic inlreitance. All that he does-all that he aspires to do and to be is motivated largely by this ingrained fear. This fear must not in any sense be limited to the individual, as such, but it is rather the consummation of all racial contributions. Were it of mere ontogeneric origin, it would mean nothing, but as a product of the race, it is all important.

Accepting President Hall's postulate, let us observe man's reactions in all that relates to the great complex act of living. Why does man live? Why does he seek life? Why does he aspire to the most complete life? He is a product of the race that has avoided the pole of death and sought the pole of love and life. Man wills to live. $\mathrm{He}$ is driven from the pole of death to live life in all its fullness. It is "the supreme affirmation of the will to live" that is motivating man. His tendency is to live life the deepest, the broadest, the longest, and the best possible. He removes from death just as far as he can. Death is primarily negative, and he wants to escape it. At his best he is intoxicated with the great act of living. The slightest thing that detracts from this fullness of life is a pull in the opposite direction. It may be ever so slight, but in the final analysis it is at bottom, death. This is the thing which man fears. The slightest ill health is a detracting force and he attempts to throw it off.

Instinctively all fear death. We use every possible means to ward it off. We enrich life in every way we can. Our culture is for the purpose of enriching life. Life at its maximum is the goal. Our hygiene; physical, mental and moral is designed to make life the best. The science of medicine is to sustain the normal. The art of the physician is to transfer pathological conditions into the normal. The theologian goes even beyond the known span of life to show the delights of a supernatural life. The philosopher offers his interpretation of life that we may have life more abundantly. The artist depicts the choicest bit of beauty that his skilled eye and dexterous hand can furnish. The musician enriches life with his harmony. The happiest, fullest, richest life-physically and intellectually, is the goal of our culture. Anything that does not contribute a means to this end we fear. We want to live. We love life. We fear death.

The fear of death is increasing in proportion to our abilities to live. Never has life been held so precious as at the present time. Never was death so feared as now. The motive for our great social and economic unrest that we are now experiencing is the desire to live. "Life was never so rich 
and joyous as now," says President G. Stanley Hall. We find our penal codes relaxing a little that life may not be untimely cut off. Society is readjusting itself that all-both rich and poor-high and low-may have life and have it more abundantly. The contributions of hygiene, sanitation, education, recreation and amusement have been to make life the sweeter. Man wills to live and all his efforts are given that he may live at his best.

The gregariousness of man leads him in this direction. $\mathrm{He}$ is a unit of a social group. $\mathrm{He}$ is constantly considering how the activities of his group will affect him. He is a part of it and the desire of the individuals to expand in living the fullest possible life becomes a factor in the group.

The tendency of the group or crowd is to expand indefinitely. This tendency is checked only by the influence of what Conley (II) terms the over-crowd, i. e., we come eventually to a group or crowd that is inclusive of all other groups and because of this it takes precedence over all others. The nation at present is the standard over-crowd. In America, for instance, a state cannot be so constituted as to in any way go beyond the federal constitutional limits. The corporations, both private and public, are restricted by the state while the individuals within these have still a closer restriction. It is through these series of groups from the individual up to the great over-crowd or nation that the instinctive tendencies of man as a unit of society manifest themselves. The tendency of the individual becomes, in so far as it can, the tendency of the group, as such. The individual aspires to the fullest possible life. He obtains it save as he is restricted by the first group, possibly the family. This group in turn aspires to the fullest life for it and in turn is limited by a still larger group. Eventually we come to the national group which seeks the fullest possible national life, and here, as society is organized today, the all-inclusive group ceases.

The nation in theory is responsible to no one. It has no superior group or over-crowd. The nation, however, has characteristics similar to those of the individual and the smaller groups. It wants life. It wants a national life and that in abundance. A nation as a nation loves life-national life-and fears national death. With the tendency of the group or nation to constantly expand and with its love of national life and fear of national death, what must ultimately result? In the end one nation must clash with another. It may be in treaty or it may be in war, but in the final analysis the clash comes. As yet there is no all-inclusive over-crowd. If a world federation could be accomplished this would serve to complete the series of precedence from individual to an 
all-inclusive over-crowd. So far as this social scheme is concerned, it would then be complete.

However, we have not gone that far. We have the nation as the largest group. Our conception of the world's history is very largely in national units. The ultimate social structure is commonly considered the nation.

It is a unit to the extent that we speak of national policy, national ideals, national customs and national life. What do these expressions mean? Why do we apply these attributes to a nation? Because it is a great organism with attributes very similar to those of the individual. We might even speak of a national soul. This great social organism loves life and fears death. It will expand and live the fullest national life possible until it is curbed by contact with other nations.

The tendency for the nation to expand is accepted. The ultimate contact with other nations is inevitable. From the moment of contact the national life is restricted in its expansion. Its natural tendency is checked. It must decide which will contribute most to its life-the avoidance of resistance to the restricting neighbor nations, thus averting war, or whether the resulting internal restriction, decay and atrophy is a greater price to pay for national life at its best than is the price of war. Here we find the nation facing two dangers-internal decay on the one hand while on the other external repression and restriction.

In the final analysis a nation must meet these fears. The one is internal, the other is external. Both are repressive and prevent the fullest national life. The nation determines which fear is greatest. If it be internal decay and death it will react in such a way as to escape it. This can only be by removing the cause for repressing its growth and expansion. This cause is another nation. When this reaction comes, if it is war-international war. Its purpose is to preserve national life.

Now the normal reaction to fear is usually anger. An individual may cower from fear for a time, but eventually anger results and he turns and fights. Apparently the fear begets anger and pugnacity. President G. Stanley Hall, Cannon and others say that anger is the one emotion into which all others tend to pass. It is easy and natural for fear to pass over into anger.

Anger is a great primary emotion. It is closely related to muscular action, according to Cannon, and the result is muscular expression. Man becomes angry and then fights. Anger stirs men to action. James (30) in his "Energies of Men," shows that anger may serve to collect great reservoirs of power. If a man has a great task to perform let him 
become angry and he consummates it with ease. It gives him his "second wind."

As it is with the individual so it is to a great extent with a nation. A national fear passes over into a national anger. Great "reservoirs of power" are formed and the nation as a unit, saturated with anger, hurls itself against another. The result is war. It is a most natural development. The neutral nation, - or at least those of a neutral nation sustained by the scholar's poise,--looks upon the clash much as a thoughtful bystander looks upon a fight between two individuals. To the psychologist the motives in either case in the final analysis are identical. There has been the old fear of death and the emotion has passed over into that of anger and fighting and war are the natural results. Anger may not always express itself in fighting. Indeed it may. be sublimated to a different channel in a majority of cases.

But be that as it may, we do find in anger a powerful motive. Much has been said derogatory of anger. No doubt the comments and warning have served a good purpose, but such a powerful emotion having such far-reaching effects demands more than passing attention. Careful students have found that the normal expression of anger-or the sublimation determined by the individual and his environment is good. It may not at first seem evident, but a careful psychoanalysis will reveal that some of our best products in various fields owe their origin largely to anger. A common illustration is that of the impassioned orator. The artist, the sculptor, the musician are motivated by these instincts. The king in finance, the statesman, the engineer, the educator, the clergyman, all are most productive when able to swing in the greatest arc between the poles of experience. He who comprehends most completely the two extremes is best fitted for the great act of living. It is the effect of fear and anger both on the individual, as such, and again in the group that is fundamental to this theme.

It has been shown that both the individual and the nation loves life and fears death. It has been shown that the emotion of fear tends to pass into anger. Anger is a great motivating emotion which may drive not only individuals separately but as a group or nation into attempting and accomplishing great tasks. It is in these emotions and their expression that we find a cause for war. It is natural and normal. Man is a killer. The history of his race is written in blood. Historic man has apparently developed this propensity as rapidly as any other. At any rate it is still present and the world's history is one long account of battle and warfare. 
The Christian era has not changed the scheme. Nor should it, if it is the sublime expression of the folk-soul. It is often spoken of as the "gospel of peace," but a careful scrutiny of some of the choicest products of the Christian religion teems with ideas derived from war.

The acme of peace is said to be in the teachings of Christianity. "Peace on earth, good will to men," has been heralded for nearly two thousand years. "Love thy neighbor as thyself " has been $a$ " foundation stone in the structure of the Christian Church. Unselfishness, meekness, "turning the other cheek" and the giving one's coat to him who steals his cloak. But concomitant with all these there has remained a spirit of warfare that has permeated the order of service, the sermons, the organization, the hymns and the prayers. The glamour of war has stamped itself so indelibly on mankind that even the Christian religion has interwaven its contributions with the teachings of Jesus. No one is surprised when people are exalted to ally themselves with the "army of the Lord "- "Onward Christian Soldiers" is looked upon as expressing the true spirit of the Christ. "Lift high His royal banner, ye soldiers of the Cross" has the dash of the military parade rather than the humility of ignominious death. Special days of prayer are set apart wherein the blessings of Deity on the armies are invoked. Statesmen, clergy and officers assure their soldiers that they are in the right-that God is on "their" side.

In hymns with a delicate touch may be found the stamp of the war influence as in the last stanza of Julia Ward Howe's Battle Hymn of the Republic:

\footnotetext{
"In the beauty of the lilies, Christ was born across the sea, With a glory in his bosom that transfigures you and me. As he died to make men holy, let us die to make men free, While God is marching on."
}

Here the sacrifice of warfare is directly compared with the sacrifice of Jesus in the great scheme of the Christian Redemption. Jesus himself asserts, "Think not that I am come to send peace on earth ; I come not to send peace but a sword." Thus we find the stamp of warfare in one phase or another even in those fields that are commonly conceived of as being farthest removed from war.

With all our culture and civilization, war has not been eliminated. Indeed, in the light of two thousand years of Christian teachings and civilization, warfare seems to have become more pronounced. The most colossal struggle, with the greatest loss of life and treasure, and the worst atrocities, has come with the culture of the twentieth century. At first 
we stand aghast at it all. And why? Why is it all so awful? By what standard do we measure? By the new standards of a generation rather than those of the race.

It has been heralded far and wide that civilization has reached the point where war will not be tolerated, and that society is able to overcome such an instinct, as that of fighting, at least by sublimation, and meet the exigencies of human society in such a way as to solve them without the sword. Recently attempts have been made to show that all the teachings evolving from the Prince of Peace are such as to reconstruct society in a way that strife shall be eliminated. To the passive mind the theory may be beautiful. In a final analysis it may be anything but beautiful. At any rate the theory is social and very new. The evolution of the folk soul has been overlooked. Recent interests are largely economic and social and for the most part war is viewed from this environment.

To those limited to this view, war is all that Sherman said it was. It is incompatible with modern civilization, according to the students of society. According to them, the time has come for the settlement of international differences without the use of the sword. Peace tribunals, peace treaties, peace prizes, peace societies have been very prominent within the last decade. They have sought to aid society in the best possible way but apparently have not convincingly presented a successful peace plan to those who have the power to declare war. This is not to be construed to mean that such movements have been failures, but since the events of the summer of 1914 , new aspects of the problems have presented themselves. From the standpoint of the student of psychogenesis and psychoanalysis fundamentals have been overlooked. Man has been considered from the ontogenetic viewpoint only, while in the instincts that motivate fighting and warfare nothing short of a philogenetic consideration can be of great worth.

It is most natural that American civilization should tend to overlook the racial tendencies of man. America is a composite nation and very new. Because of her youth her traditions are necessarily recent. But in addition to this short span of time, the growth and expansion have been so rapid and so great that our meagre and youthful traditions have been all but lost. Add to this the influx of immigration from every quarter of the globe and the wonder is that any traditions have survived. As a result there are no racial traditions, language is more diversified than in any other great nation, and with no royalty or ruling family, tradition has been reduced to the minimum. 
With all this, together with unequaled prosperity, economic and social progress it is no wonder that man, stripped of his culture, a product of the race and bearing all its imprints, has been overlooked save as he appears in his cloak of civilization. Because of this, war has been little thought of in America. America has thought of peace and with unprecedented commercial development and the resulting international relations, has sown the seeds of peace broadcast.

All was well until the summer of 1914, when in the twinkling of an eye,-to many-the war clouds gathered and a world war such as the world had never seen was precipitated. It was a shock to the civilized world, and more especially to America. It had not been expected-it had not been even dreamed of. America had evolved a standard almost purely economic, that discredited anything that smacked of war. Her teachings were and had always been those of peace and now a world war struck terror in her very soul. It was all terrible. And why terrible? It was out of harmony with American teaching and standards of living. But how old are these new economic, social and industrial standards? Since when has someone proclaimed the "Great Illusion" of economic waste? When was the biological aspect presented showing war a loss to the race? When did the new socialistic wave first sweep over the civilized world? Within about a hundred years. We have a little infant standard of perhaps a century to measure a racial tendency as remote in origin as the race itself. We have, according to Patrick (47), the same old brain of our fathers and forefathers stamped with ancestral traits and primitive instincts which cannot quickly be outgrown. We have splashed on a bit of veneer and the spots from which the veneer may be removed only appear the worse from contrast. There has been a sudden change in society, but the individual is the same. He inherits the philogenetic traits and no matter what society may decree, as society, man cannot quickly and at once put aside racial characteristics.

Man has never been content to labor without reference to his associates. In fact anywhere along the line of civilization there are abundant illustrations of the strong exploiting the weak. Patrick says the modern state is the historical development of the primitive group. There has always been within the group a tendency for the strong to exploit the weak. And yet when the group is threatened by a common enemy, the factions unite as by magic. The exploitation of the weak by the strong perhaps was never more prevalent than at the present time, but here again in the great European war is shown a group loyalty of unrivalled quality. Not only have 
the nations become units, but alliances between different races have been made that the great ambition of the nation might be realized.

English and French, though once at enmity, are united as one; Russia and Japan, though recently at war, are allied in a common cause ; Germany, with all her Christian civilization, has as her ally the "unspeakable Turk." Never in the world's history have so many of the common bonds such as religion, race, language, color and tradition been broken as in the European war. How are we to explain it? Does any argument approach an explanation as that relating to a recrudescence to the primitive? How shall we explain an annihilation of so many of the contributions of civilization?

Freud (2I) says we are too near the European war to pronounce a correct judgment on its meaning. He continues by saying that there has never been any event that "destroyed so much of the precious possessions of mankind!" The clearest minds are confused and even science has taken on a more or less passioned partiality and some have become so embittered that they have flown to arms. The anthropologist thinks his enemies minderwertig and degenerate while the psychiatrist has diagnosed the enemy as more or less insane. Freud shows the peculiar difficulty in comprehending in that only the soldier can have first-hand knowledge. But he, if he be a true soldier, and in the thickest of the fight, is in a poor position to furnish us very valuable data. The psychological investigator, on the other hand, must work at long range, with the result that much of the most valuable data cannot be secured. However, disregarding an attempt to analyze this particular war, we do find evidence of the old instincts. The Freudian doctrines sustain the fact that civilized or cultured man possesses the same brain as the savage so far as structure and weight are concerned, and that the difference is functional rather than structural.

War is a recrudescence of the infantile unconscious of the human race destroying for the time being all the accumulations of civilization and culture.

Pfister (49) shows that war is constantly becoming more cruel and that apparently with the advance of culture the recrudescence becomes more complete-that the regression goes farther back and that war becomes more cruel and primitive, that the fighting instinct or war trend may cause a soldier to shoot a father today and tenderly care for his children tomorrow.

It is difficult for people to realize that the war spirit is primitive and that the standards of civilization as used today are for the most part very new. When the culture is stripped 
off, however, the war lust is exposed. The fighting instinct, or war lust, is never entirely overcome. Though it may seldom break out, it is only repressed. These instincts are well hidden until there occurs an inhibition of life. Then, says Jung, it is like a dammed stream, the waters of which set back towards the springs and fill up old canals that have emptied.

In an analysis of this regression to the primitive, President G. Stanley Hall raises the question: "What are the kinds of these connections or chains?" and in answering, admirably summarizes as follows: There are three views: I. Freud thinks that most important are the complications or nodes of the love life that repel regression and make us dependent on the unconscious, on infantile ideas and feelings. 2. Adler says it is due to the loss of clear and free self-determination that arises from physical injury or defect, bringing a feeling of inferiority which arouses the manly protest. According to this, then, it is the need of Geltung that plunges man in regression and brings him under the power of unconscious childish impulses. 3. Jung thinks that the bifurcation which subjugates the spirit of domination of unconscious infantile powers is due to the opposition of a tendency of persistence or development. Whoever resists an inner impulse to a high achievement falls under the rule of regression, so that he is a prey to the unconscious primitive archaic thoughts and acts.

While these primitive tendencies-these regressions-may be more or less disheartening to those who conceive the cultured man as the type man, under all circumstances and conditions, still there is a value in the consideration of this recrudescence. The instincts are present and when action in the human being is demanded it is largely the instincts that motivate. When our culture and education are such as to sublimate completely these instincts into the channels of art, literature, music, religion or other phases of culture, then may we hope to use our newer standards.

For a nation, in time of war, anything is right. "All is fair in war." It is apparently ethical for a nation to resort to trickery, deceit, surprise, thieving, ravishing, torturing and persecution. The one aim is to win. National life and spirit is at its highest. Differences within the nation tend to disappear. The group consciousness is aroused, the fighting instinct asserts itself, all the hatred, suspicion and viciousness of the race is revived and a desire to exterminate the enemy, if need be, takes possession. The nation becomes a unit. Nationalism is paramount. Policies that would not be tolerated for an individual or lesser group receive a nation's stamp 
of approval. A few individuals deplore the atrocities attendant upon the struggle, but their voice is feeble. The nation is not bound to the ethics of the individual. In a national struggle, what of it if a few atrocities be perpetrated? The nation's life is at stake. Everything transpires under the caption of patriotism which to the mind in passing is all that is good and wholesome. As the clash comes and the fight continues, these outcroppings are overlooked and all are sucked into the great war current. The whole nation is at wareverybody is fighting. All of one nation is the enemy of all in another. Those noncombatants of the opposing nation who are guests or residents in a nation are subjected to direct insults. Even foreign names are tabooed. Never perhaps have nations gone to such straits in these small matters as in the European war. International courtesies are withdrawn. The Germans will not countenance English words or even derivatives. St. Petersburg as a name becomes only a relic. Fortescue reports (20) that in Berlin every English and French name disappeared in one night. The Hotel Bristol, which has a name that is a considerable asset, became the Conrad Uhl after the manager. The Westminster Hotel became the Station House and the Piccadilly Café did a thriving business under the title Vaterland. One of the Berlin jewelers who had the time of the world showing on several clocks, is reported to have pasted out the faces of those registering the hour in London, Paris, Petrograd and Brussels.

Even men of broad training became extreme and biased in their comments and praises of their country. M. Hirschfeld (27) raises the question, "Warum hassen uns die Völker?" and then proceeds to answer it by saying that it is a mere matter of jealousy, ignorance and envy on those who disagree with Germany. In short, only merit has advanced Germany while envy and jealousy on the part of other nations have sought to throttle her.

J. W. Allen (I), representing England, on the other hand, in "The Danger of Peace," urges that when peace is declared, "The treaty must represent agreement between us and our allies : not agreement between us and Germany."

Rene Doumic ( 18 ), in an address given before the Institute of France (which includes the world-famous French Academy) apologizing that he must appear in academic costume rather than in a soldier's uniform, declares that French history is but the history of French valor.

The natural law to which all laws of nature can be reduced is the law of struggle. All that we have and hold most dear is at bottom the result of struggle. This is true both of the individual and the group. Says Clauss Wagner, "The in- 
ternal development, the introsocial struggle, is man's daily work-the struggle of thoughts, feelings, wishes, sciences, activities. The outward development, the supersocial struggle, is the sanguinary struggle of nations-war. In what does the creative power of this struggle consist? In growth and decay, in the victory of the one factor and in the defeat of the other! This struggle is a creator, since it eliminates." (Clauss Wagner, "Der Krieg als schaffendes Weltprinzip.")

War is the great unifier of a nation. The first tendency on the part of man is to assert his own rights, but in a great social struggle the self and under group lose their identity and all fall in for the national struggle.

Who is regretting the work of the soldier in time of war? Not the soldier. Many a young, virile man does not volunteer in a crisis until he is sure he will see "actual service." He wants an opportunity to fight.

In the following illustrations and reports one may get a view of the individual's reaction to war. There is a recrudescence of consciousness and social and ethical standards are shattered. A sort of "war complex" is established. Barbaric traits appear as the war spirit develops, and there is a general reversion to the primitive.

Richard Harding Davis (14) reports how quickly and completely men became accustomed to war. It becomes a business. War becomes a series of commonplace incidents. There is a regression to the primitive and such an incident as selfpreservation becomes the motivating factor.

Carrington (9) has made a study of what the soldier going into battle thinks. He raises the question as to what occupies the soldier's mind while in the trenches. What feelings animate him when he attacks, charges or thrusts his bayonet into the flesh of an antagonist is the question. Just how is the civilian transformed into the soldier? He postulates two zones-a "war-zone" and a "civil-zone," the first shading off into the second. He gathers his data, so far as possible, from the soldiers while within the "war-zone" before the influence of the "civil-zone" may exercise a bias. He first makes a study of the "rest-camps" Cantonment. Here the soldiers have a co-operative community life.

The greater part of the activities are manual, however, and Carrington points out that the activities being so largely manual and so circumscribed, tend to make the mind simple, primitive and almost vacuous. The soldier makes little or no attempt at original thinking, but depends upon the officers. He tends to become a " $\operatorname{cog}$ in the wheel." In fact, initiative on the part of the soldiers is not to be desired. That is for the officer. In going toward the front the confidence of the 
soldiers increases. There is a unifying of the group and all believe that they are sure to succeed. This confidence seems to increase in a direct ratio as the front is approached.

In the trenches there may be momentary pangs of fear or uncertainty, but the presence of comrades, for the most part, dispel them. Here, amid the scream of shells, the rain of bullets and the sight of blood, the wounded and dead- "familiarity breeds contempt." In the movement of troops there is such a unity that the individual vanishes, as such, and he believes his safety lies in acting in unison with his associatespersonal psychology gives way to the psychology of the crowd. The soldier enters the trenches as a matter of course.

A young corporal reports: "I am not sure that I thought of my family particularly, even when writing home! There seemed somehow to be a veil between us, shutting off all communication of feeling and interest between us." In the isolated trenches farthest to the front, the mind becomes even more empty and blank. The great danger here apparently is the morale of thinking of being deserted by other parts of the army. In the attack, the soldier is conscious only of the self. Country, family and God may form a subconscious background, but the conscious thing is the avoidance of the "mortal shock." The one object is to destroy the immediate enemy. This becomes so strong at times that the officers can scarcely restrain the men from hurling themselves against the enemy. "When we all advance, no one is afraid," reports one soldier. In making a bayonet attack the purpose of every soldier is the complete destruction of his enemy. It is not murder to him-it is self-defense. "Each soldier killed lessens my own chance of being killed." A soldier reporting on bayoneting an enemy says: "I had a curious sensation in my arms as I felt the soft body, and I grew fatigued with continued fighting. But the action was of such short duration and I felt all the time so keenly that I was fighting for my life, and seeking only to preserve myself, by killing the enemy, that I gave no thought of him." Thus culture is, for the time being, swept away and a primitive brute-beast remains fighting with no other ideal than those of his primitive ancestors-self-preservation.

Liddell reports (38: p. 178): "All manner of wounded came along. Those whose wounds were slight helped their badly-hurt comrades on. All the soldiers were dust-covered, sweating and mostly bareheaded. But they were all full of spirit. They looked repeatedly back towards where they had come from, as if reluctant to leave the scene of action. They allowed us to handle their broken limbs and bleeding, gaping wounds without murmuring. They seemed indifferent to 
pain. Their eyes still shone bright with the excitement of battle. Their besmeared faces were full of eager interest."

Speaking of the women in the war, Washburn $(6 \mathrm{r}: \mathrm{p} .103)$ tells of a countess acting as a nurse who calmly remarks: "Two weeks ago I could put two fingers up to my hand in this man's brain. Yet we have fixed him up and he will recover." The attending surgeon remarked that this countess had on several occasions remained on duty without sleep or rest for fifty hours.

Fortescue (20) writes of conversing with a "mild-mannered, blue-eyed fat Teuton, the type you expect to see drinking beer and rearing a large family, doing the most bloodthirsty deeds all at the call of the Kaiser." In his recital of his flight over cities dropping bombs on defenseless women and children there seems to be no feeling of cowardice or regret.

Irwin (29: p. 129) reports the trip of an aeronaut as follows: "When you start," he said, "you make up your mind that you're dead. Of course, you will be sooner or later. When they get you and you're four thousand feet in the air, there's no escape. My case (a safe return) just happens to be a miracle. And after you've fully made up your mind to die, it's a glorious sensation! You can't know how cheerful a man feels up there!"

Many imagine that the women at home have but the one interest-that of a safe return of husband, son or brother, and that a wound is only a cause of worry. But witness the following account by Fortescue (20: p. II3) who writes: "When our train approached Berlin, one got a picture of the other side of war. Many little pathetic scenes were enacted at the different stops. The news of the coming of the wounded had been wired ahead. Mothers, wives and daughters gathered to meet their loved ones. I remember one girl - she had the air of still being a bride-almost smothering her husband with kisses. Talking like a runaway phonograph, her eyes never left his face. Her own were lit with pride and love, yet while I watched, she never let her glance wander to the shattered arm her husband covered in a sling. As the train pulled out, I saw her still smiling up at him in rapture, oblivious to the world."

For the most part, these experiences indicate the naturalness of war. It is a matter of course. Man is adapted to war, as he is adapted to eat and sleep. There may be thrills of terror when war is announced, but as time passes, the attitude changes until war is looked upon as a beneficent thing. It is a return to the primitive, and is comparable in many ways to the movement of "back to the soil," save that 
the recrudescence is more complete in war than it is in the simple tilling of the soil.

War may be a terrible crucible in many ways, but some of its products are exceedingly valuable and bright. James (3I) believes that if a vote were taken to expunge from the history of the United States, the war for the union, only a handful of eccentrics would say yes. The ideals and memories of those days are among the most precious and sacred things we possess. Says James, "Our ancestors have bred pugnacity into our bone and marrow, and thousands of years won't breed it out of us. The popular imagination fairly fattens on the thought of war. Let public opinion once reach a certain fighting pitch, and no ruler can withstand it." War is a sacrament. Both victor and vanquished profit. Militarism is the great preserver of our ideals of hardihood. There is a type of military character which everyone feels the race should breed.

James hopes for peace, but says, "The war party is assuredly right in affirming and reaffirming that the martial virtues, although originally gained by the race through war, are absolute and permanent human goods." "When the contemporary man steps from the street of clamorous insincere advertisement, push, adulteration, underselling and intermittent employment, into the barrack yard, he steps on to a higher social plane, into an atmosphere of service and cooperation and of infinitely more honorable emulations."

This study has led to the conclusion that the fundamental cause of war is not economic, nor the product of organized society, but that in the final analysis, war is motivated by primitive instincts. The emotions of fear and anger and their relation to the "will to live," are philogenetic, ever present, and constitute important factors in the production of war. Furthermore, man is instinctively a killer, and the inhibitions of modern civilization are temporary and a frequent recrudescence or return to the primitive is inevitable. The evidence of the European war has shown that the more advanced the civilization, the more primitive will man become when once the inhibitions are removed and the instincts are unleashed.

To the geneticist and the psychoanalyst, this is commonly recognized, but to those overlooking these factors and holding to a limited economic and social interpretation, there may come a surprise. This confusion, according to our findings, is caused by an attempt to measure primitive instincts, as old as the race, by social and economic standards that have been evolved within a very few years. The failure of this inter- 
pretation is self-evident, and we believe that nothing short of a philogenetic consideration can interpret war.

The development of nationalism is fundamentally an action of the group, and the group, as such, retains the psychic characteristics of more primitive times. Our much-talked-of civilization is, after all, little more than an extension of our organs whereby the group may more readily be enlarged and yet function as did the smaller groups of primitive times. By extension of organs, we mean that modern transportation is little more than the lengthening of the legs and strengthening of the back of primitive man; that telegraphy, telephony, and fast mails merely increase his conversational distance and abilities, while modern machinery for producing clothing, shelter and food, and even implements of war, is little more than a perfecting of the arms, hands and fingers of man, who so recently has been limited to the tribe and city state.

It is this external thing that has screened from the eyes of many, man's psychic nature as a product of the race. The curtain has been drawn again and again, but not until the advent of the European war, bursting in, as it did, upon twentieth century culture, did the rude awakening come. Through this war, man's nature was laid bare, and in this exposure were revealed the indelible stampings of the race from his remotest ancestry to the present time. In sustaining these findings, specific incidents have been cited. In these incidents are to be found both objective and introspective data corroborating this view.

Finally, substitutes for war have been considered, and there are elements of value in all that have been suggested, but neither singly nor in composite has an adequate substitute been found. In this respect we can only suggest that when all society has been educated with the full recognition of psychogenetic factors, and when we know more of the successful sublimation of primitive instincts than we now dream of, then, and not until then, may we hope for the passing of war.

\section{BibLIOGRAPHY}

I. Air.s, J. W. The Danger of Peace. London, 1915. $37 \mathrm{p}$.

2. Andler, Cras. "Frightfulness" in Theory and Practice as compared with Franco-British War Usages. London, 1916. I8I p.

3. Bukgmann, E. Philosophie und Krieg in der Kampf des deutschen Geistes im Weltkrieg. 1915. 215 p.

4 Bergson, $H$. The Meaning of War. T. Fisher Unwin Ltd., London, 1915. $215 \mathrm{p}$.

5. Bernhardi, F. von. Germany and the next War. N. Y., Igiz. $288 \mathrm{p}$.

6. Butrke, N. M. The International Mind. Scribners, N. Y., 1912. I2I $p$. 
7. Cannon, W. B. The Interrelations of Emotions as Suggested by Recent Psychological Researches. Am. Jour. Psy., Vol. 25, I9r4. pp. 256-282.

8. pleton, N. Y, 1915. 437 p.

9. Carrington, $\mathrm{H}$. The Mind of the Soldier. Forum, Jan. Igi6, Vol. 15. pp. 49-68.

io. Chamberlain, H. S. Foundations of Nineteenth Century. Lane, N. Y., IgII (2 vol.) I, 576 p. II, 580 p.

II. Conway, M. The Crowd in Peace and War. Longmans, Green \& Co., N. Y., I915. 332 p.

12. Dane, E. Hacking Through Belgium. Doran, N. Y., I9I4. $176 \mathrm{p}$.

13. Davis, M. M. Psychological Interpretations of Society. Columbia University, N. Y., 1909260 p.

14. Davis, R, H. With the Allies. N. Y., I9I4. 241 p.

15. Dewey, J. German Philosophy and Policies. Henry Holt \& Co., N. Y., I9I5. $132 \mathrm{p}$.

16. Dewitz, Baron H. von. War's New Weapons. Dodd, Mead \& Co., N. Y., 19I5. $285 \mathrm{p}$.

17. Dix, K. W. Psychologische Beobachtungen über die Eindrücke des Krieges auf einzelne wie auf die Masse. 10I5. $30 \mathrm{p}$.

I8. Doumic, R. The Soldier of 1914. N. Y. Times Current Hist. Vol. I, p. 156.

19. FISHER, IRVING. Report on National Vitality. Washington, Igog. $138 \mathrm{p}$.

20. Fortescue, G. At the Front with Three Armies. Brentanos, London, 1915. $271 \mathrm{p}$.

21. FreUd, S. Zeitgemässes über Krieg und Tod. Die Enttäuschung des Krieges. Imago, I9I5. pp. I-2I.

22. Half G. S. Anger as a Primary Emotion and the Application of Freudian Mechanisms to its Phenomena. Jour. Ab. Psy., Vol. X, pp. 8I-88.

23. - A Synthetic Genetic Study of Fear. Am. Jour. Psy., Vol. 25, 1914. pp. 149-200.

24. - - A Study of Anger. Am. Jour. Psy., Vol. 1o, 1899. pp. 516-59r.

25. Hansbrough, H. C. War and Women. Duffield, N. Y., I9I5.

26. Hrbmen, J. G. The Higher Patriotism. Scribners, N. X., I9I5.

27. Hursch feld, M. Warum hassen uns die Völker? Berlin, I9I5. $43 \mathrm{p}$.

28. Howard, Frank. Anger. Chap. IV, Doctor's Dissertation, Clark Univ.

29. IRwin, W. Men, Women and War. Appleton, London, 1915. $192 \mathrm{p}$.

30. James, W. The Energies of Men. Moffat, Yard \& Co., N. Y., I911. $38 \mathrm{p}$.

3I. - The Moral Equivalent of War. Pop. Sci. Mon., Vol. 77, 1910. pp. 400-410.

32. Johnstone, H. M. The Foundation of Strategy. London, 1914. $208 \mathrm{p}$.

33. Jones, E. Sociological Rev. Vol. viii, 1915. pp. 167-180.

34. Jordan, D. S. War and Waste. Doubleday, Page \& Co., N. Y., I913. $296 \mathrm{p}$.

35. LADD, G. T. The Human Mind versus the German Mind. Hibbert Jour., Vol. 14, 1916. pp. 300-319.

36. LAmszus, W. The Human Slaughter House. Frederick A. Stokes Co., N. Y., 19r3. II6 p. 
37. LE Bon, G. Enseignements psychologiques de la guerre europeene. Paris, 19r5. 364 p.

38. LiDDELL, $R$ S. The Track of the War. London, 1915. $276 \mathrm{p}$.

39. McDougal, W. Introduction to Social Psychology. Methuen \& Co., London, 1908. $355 \mathrm{p}$.

40. Machen, A. The Bowmen. Putnam, N. Y., 1915. $77 \mathrm{P}$.

41. Mackaye, P. A Substitute for War. Macmillan, N. Y., 1915. $55 \mathrm{p}$.

42. Matthews, F. A. If War Comes to Me. N. Y. Times, Jan. Igie.

43. Mrluond, M. M. Historic Causes of the War. N. Y. Times, Sunday, Jan. 24, 1915 .

44. Mitchei.l, P. C. Evolution and the War. Dutton, London, 1915.

45. Murray, G. The Herd Instinct and the War.

46. Novrcow, J. War and Its Alleged Benefits. Henry Holt, N. Y., 1911. I30 p.

47. Patrick, G. T. W. The Psychology of War. Pop. Sci. Mon., Vol. 87, pp. I55-168.

48. Perris, G. H. The Campaign of 1914 in France and Belgium. Holt, N. Y., 1915. 447 p.

49. Pfister. Zur Psychologie des Krieges und Friedens. IgI4.

50. Powell, E. A. Fighting in Flanders. N. Y., I914. 231 p.

51. PRINCE, M. The Psychology of the Kaiser. Badger, Boston, 1915.

52. Pulf, E. Die Panik im Krieg. Munich, Igo8. $78 \mathrm{p}$.

53. REICH, E. Germany's Swelled Head. Andrew Melrose Ltd., London, I914. I75 $\mathrm{p}$.

54. RIBOT, T. The Psychology of the Emotions. Scribners, N. Y., I897. $455 \mathrm{p}$.

55. Sarolea, C. How Belgium Saved Europe. Lippincott, London, 1915. $226 \mathrm{p}$.

56. Stabarzt, W. Militar-psychiatrische Beobachtungen und Erfahrungen. 1915. I45 p.

57. TAYLOR, G. R. S. The Psychology of the Great War. Martin Secker, London, 1915. I95 p.

58. Tews. Der Kampf des deutschen Geistes im Weltkrieg.

59. Titchener, E. B. A Textbook of Psychology. Macmillan, N. Y., 1915. 565 P.

60. WaGNER, C. Der Krieg als schaffendes Weltprinzip.

6i. Washburn, S. Field Notes from the Russian Front.

62. Vivian, E. C. The British Army from Within. London, 1914. $182 \mathrm{p}$.

63. Younghusband, F. The War and Spiritual Experience. Atlantic Mon., Vol. 116, 1915. pp. I34-139. 